\title{
BLOOD TRANSFUSION-RELATED IMMUNOMODULATION
}

\author{
Luciana do Nascimento Vargas ${ }^{1}$, Laís Oliveira Garcia', \\ Ananda Cristine Santos Galvão', Tor Gunnar Hugo Onsten ${ }^{1,2}$, \\ Adriana Simon Coitinho ${ }^{3}$, Leo Sekine ${ }^{1}$
}

\begin{abstract}
The phenomenon of transfusion-related immunomodulation (TRIM) has been studied since the observation of a higher kidney allograft survival in patients who had received a higher number of transfusions. Conversely, it has been suggested as one of the possible causes related to the development of infections in patients with multiple blood transfusions and/or after a major surgery, and has been also associated with a decreased function of natural killer cells (NK) and antigen-presenting cells (APCs), reduced cell-mediated immunity, and increased regulatory $T$ cells (Tregs). This review aimed to conceptualize TRIM and discuss some aspects related to its mechanisms and the prevention of immunomodulatory events.
\end{abstract}

Keywords: Immunomodulation; blood transfusion; immunosuppression; infection; leukocytes

Blood component transfusion, as any other medical intervention, involves risks and benefits that should be individually assessed for each patient. Although blood transfusion guidelines usually do not follow a unique approach, there is growing amount of data in the medical literature to support individualized hemotherapy decisions ${ }^{1}$. The immunosuppressive effects of red blood cell (RBC) transfusion were firstly reported in 1973, when a higher kidney allograft survival rate was observed in transplant patients who had received a greater number of packed red blood cells (PRBCs) ${ }^{2}$. Subsequent clinical and laboratory investigations corroborated these data, which led to the deliberate use of allogeneic blood transfusions as a prophylaxis against graft rejection for a short period in the $1980 \mathrm{~s}^{3,4}$. Aggregate findings from previous studies seem to indicate that patients who need blood component transfusion have a higher risk of bacterial infection in the postoperative period compared to patients who did not receive transfusions ${ }^{5-7}$. Three possible mechanisms have been defined as the basis for the apparent association between transfusionrelated immunomodulation (TRIM) and infection ${ }^{7-10}$ : immunologically active allogeneic leukocytes, allogeneic leukocyte-derived soluble mediators, and human leukocyte antigen (HLA) peptides soluble in allogeneic plasma. These mechanisms are described below.

\section{Immunologically Active Allogeneic Leukocytes}

In blood transfusions, donor antigen presenting cells (APCs) may lose their ability to promote costimulation after being stored under refrigeration, either due to a reduction in the expression of B7-1 or B7-2 molecules or to the binding of these molecules to the recipient cytotoxic T-lymphocyte-associated protein 4 (CTLA-4), a T-cell receptor for B7 molecules. This interaction between donor APCs and recipient naive T cells may induce T cell anergy and promote immunosuppression (figure 1$)^{7}$.

Donor dendritic cells, which express CD200 or OX-2 (an immunoglobulin transmembrane protein), bind to their receptors (CD200R or OX-2-R) in the recipient myeloid dendritic cells and T cells, which suppresses macrophage
Clin Biomed Res. 2014;34(4):333-341

1 Serviço de Hemoterapia, Hospital de Clínicas de Porto Alegre. Porto Alegre, RS, Brazil.

2 Departamento de Medicina Interna, Universidade Federal do Rio Grande do Sul (UFRGS). Porto Alegre, RS, Brazil.

3 Departamento de Microbiologia, Imunologia e Parasitologia, Universidade Federal do Rio Grande do Sul (UFRGS). Porto Alegre, RS, Brazil.

\section{Corresponding author:}

Luciana do Nascimento Vargas E-mail: Invargas@hcpa.ufrgs.br Hospital de Clínicas de Porto Alegre Rua Ramiro Barcelos, 2350.

90035-903, Porto Alegre, RS, Brazil. 
A) Normal immune response
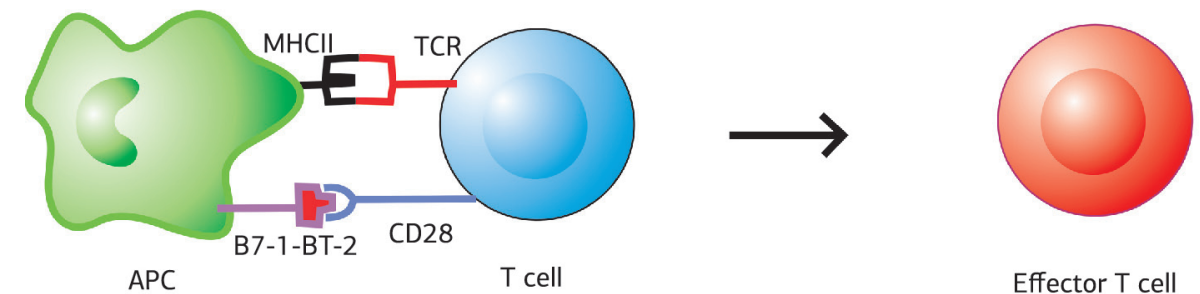

Effector T cell

B) Immune response after refrigeration

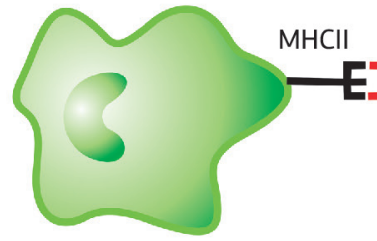

Donor APC

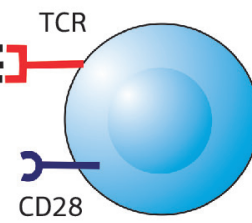

Recipient T cell

C) Immune response after refrigeration

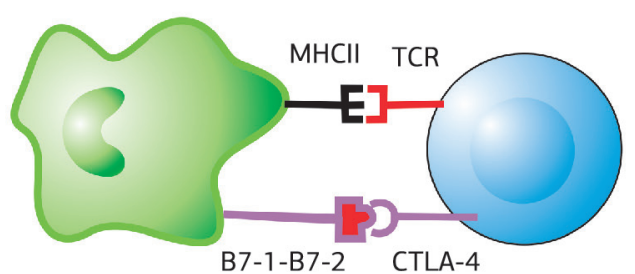

Donor APC

T cell

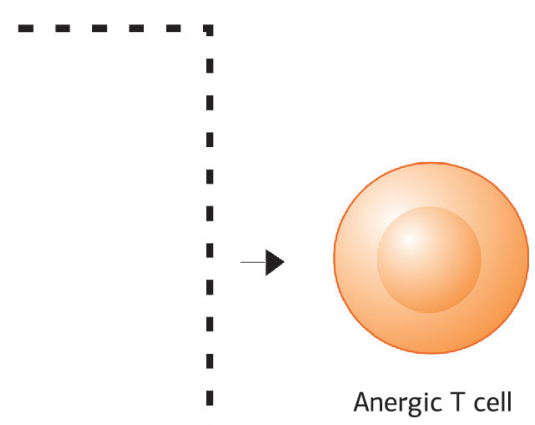

Figure 1: A) Normal immune response showing the binding of major histocompatibility complex class II molecules to the T-cell receptor (MHCI $\leftrightarrow$ TCR) and between the costimulatory molecules B7-1/B7-2 and CD28 (B7-1/B7-2↔CD28), which activates the $T$ cell and turn it into an effector cell. After refrigeration, $T$ cells undergo anergy due to two mechanisms; $B$ ) donor antigen presenting cells (APCs) reduce the expression of B7-1/B7-2 molecules or $\mathrm{C}$ ) the B7-1/B7-2 molecules of APCs bind to recipient cytotoxic T-lymphocyte-associated protein 4 (CTLA-4) molecule? ${ }^{7}$.

function, especially due to the release of transforming growth factor beta (TGF- $\beta$ ) from recipient T cells ${ }^{11}$, with consequent host immunosuppression against infectious agents ${ }^{12}$. This interaction between CD200 and CD200R has been suggested to be required for TRIM (figure 2) ${ }^{13}$.

Another mechanism related to immunomodulatory events is the phenomenon of microchimerism, which occurs when there is such a high HLA compatibility between donor and recipient that a small number of donor lymphocytes and APCs remain in recipient circulation or organs ${ }^{7,14}$. Microchimerism may also induce the development of type 2 T-helper cell
$\left(T h_{2}\right)$ response and the release of cytokines such as interleukin 4 (IL-4), interleukin 10 (IL-10), and TGF- $\beta^{15,16}$. These biological products are able to inhibit type $1 \mathrm{~T}$-helper cell $\left(\mathrm{Th}_{1}\right)$ response and macrophages activation ${ }^{15-17}$, a reaction mediated by host immune response and leads to reduced secretion of cytokines such as interleukin 2 (IL-2), interleukin 12 (IL-12), and interferon gamma (IFN- $\mathrm{\gamma})^{18}$. Therefore, the presence of donor cells may cause a down-regulation of patient's immune response, resulting in donor tolerance to alloantigens and increased recipient predisposition to infections $\mathbf{s}^{7,14,19}$. 


\section{Allogeneic Leukocyte-Derived Soluble Mediators}

Proinflammatory soluble mediators accumulated in blood components during storage have also been implicated in TRIM pathogenesis ${ }^{20-22}$. These mediators are usually located in the intracellular granules of donor leukocytes and are released over time during storage and granule deterioration ${ }^{23}$. An observational study that investigated the possible mechanisms of TRIM found an association between the number of allogeneic blood transfusions and duration of mechanical ventilation, a finding that may be explained by the accumulation of leukocyte-derived soluble products in the supernatant of the stored PRBCs ${ }^{24}$. Available evidence suggests that histamine may be a mediator of immune regulation ${ }^{25}$ and that eosinophil cationic protein, eosinophil protein $\mathrm{X}^{26}$, myeloperoxidase, and plasminogen activator inhibitor ${ }^{27}$ may also contribute to the development of immunosuppression.

Two studies reported the presence of soluble Fas ligand (sFasL) molecules - coming from the membrane of the stored leukocytes - in the supernatant plasma of donor PRBCs ${ }^{28,29}$. When sFasL is infused concurrently with blood components, these molecules may bind to Fas molecules of recipient natural killer (NK) and cytotoxic T (Tc) cells, which prevents the binding of Fas molecules of immune system cells to FasL molecules of infected cells ${ }^{30,31}$. Thus, infusing sFasL together with blood components may compromise the function of recipient NK and Tc cells, because it prevents the apoptosis of infected cells (figure 3$)^{18,30,31}$. Although there are no studies proving that blood cells undergo apoptotic changes during storage under refrigeration, the infusion of apoptotic cells has been recently found to have an immunosuppressive action in animal models ${ }^{32}$. Immunosuppression resulting from the infusion of these cells may be related to the release of TGF- $\beta$.

\section{HLA Peptides Soluble in Allogeneic Plasma}

It has been suggested that peptides derived from non-polymorphic HLA class I (HLA-I) molecules induce nonspecific antigen immunosuppression, whereas polymorphic HLA-I molecules have antigen-specific immunomodulatory effects ${ }^{33-36}$. Additionally, allogeneic plasma containing soluble HLA may possibly cause a clonal expansion of $\mathrm{T}$ cells directed against donor alloantigen and enter the circulation from the recipient thymus ${ }^{37-39}$. Soluble HLA may also be the responsible for the decrease in NK cell activity ${ }^{40}$.

\section{Other Possible Mechanisms}

PRBC supernatant induces the activation of regulatory T cells (Tregs), which produce IL-10 and TGF- $\beta$ and may suppress T cells and APCs ${ }^{41,42}$. The mechanism that may lead to Treg activation in the recipient results from the presence of IL-2 in PRBCs and of thrombospondin-1, vitamin A metabolites,

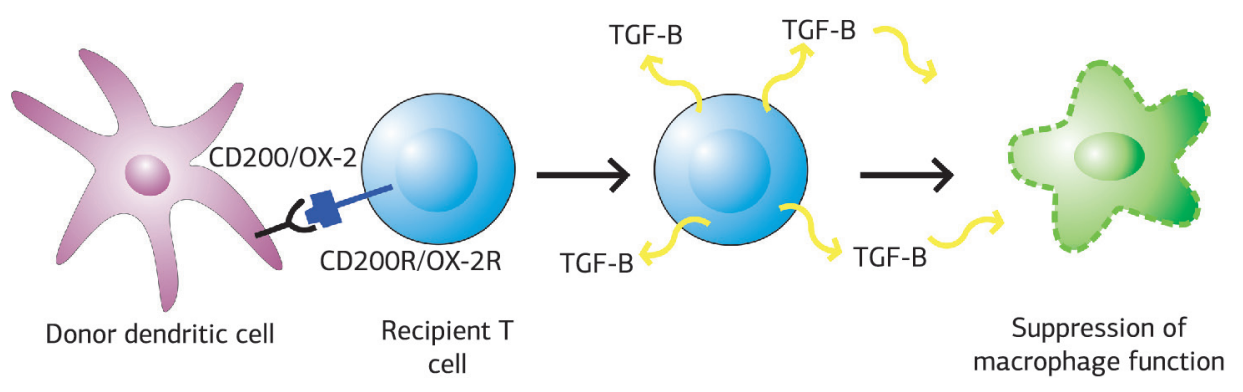

Figure 2: The binding of the CD200 or OX-2 molecule of donor dendritic cells to CD200R or OX-2R molecules of recipient T cells leads to the release of transforming growth factor beta (TGF- $\beta$ ) and consequently to the suppression of macrophage function, thus reducing host immune defense ${ }^{11-13}$.

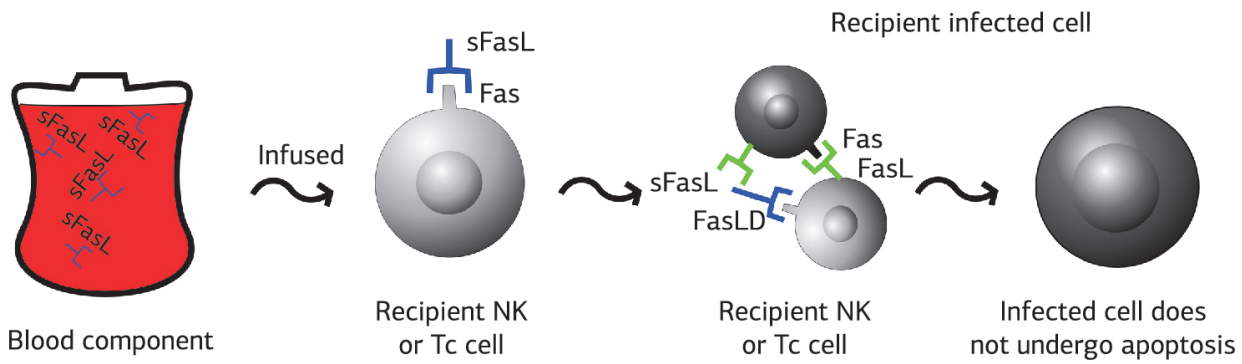

Figure 3: Soluble Fas ligand (sFasL) molecules present in the blood component, when infused into the recipient, may bind to Fas molecules of recipient natural killer (NK) or cytotoxic T (Tc) cells, thus preventing the apoptosis of host infected cells. 
heme oxygenase- 1 , and prostaglandin $E_{2}$ in the plasma fraction ${ }^{41}$. Other possible mechanism of immunosuppression is the production of anti-idiotypic antibodies. In this case, the transfusion stimulates a primary immune response against allogeneic antigens. The T-cell receptor (TCR) and the antibodies produced are considered "new antigens"; thus, the recipient produces an antibody matrix against these new antigens $\mathrm{s}^{43,44}$. After multiple transfusions, a network of anti-idiotypic antibodies may be present and react against multiple determinants of TCRs and antibodies ${ }^{43,44}$. When a graft is performed, these antiidiotypic antibodies reduce rejection by potentially interfering with TCRs and MHC molecules ${ }^{43,44}$. Although there is no proof that these antibodies control immune response, renal transplant patients with detectable anti-idiotypic antibodies have been shown to have greater graft survival ${ }^{45}$. Certainly none of these mechanisms occur in isolation but rather in synergy ${ }^{18}$.

\section{Adverse Effects Related to Immunomodulation}

TRIM has been associated with a decreased function of NK cells and APCs, reduced cell-mediated immunity, and increased Tregs ${ }^{17,46}$. However, the effects that these changes may cause on the organism are still under investigation. Table 1 shows studies evaluating the effects attributable to immunomodulation ${ }^{46-54}$. In an article published by Rogers et al. ${ }^{47}$, a dose-dependent relationship was observed between the number of PRBC units $(U)$ received during hospital stay and the prevalence of infection: $13.6 \%$ for $1-4 \mathrm{U}, 25.3 \%$ for $5-49 \mathrm{U}, 30.8 \%$ for $50-99 \mathrm{U}$, and $33.3 \%$ for $100 \mathrm{U}$ or more. In a retrospective analysis of trauma patients to assess the relationship of immunomodulation with acute respiratory distress syndrome (ARDS), Chaiwat et al..$^{49}$ observed that, regardless the type or severity of injury or pneumonia, transfusion of more than $5 \mathrm{U}$ of PRBCs during the first 24 hours after admission increased the risk of ARDS in $6 \%$ and hospital mortality in $5 \%$. Conversely, Shorr et al. ${ }^{51}$ focused their research on the development of ventilator-associated pneumonia (VAP). Based on an analysis of 1,518 patients on mechanical ventilation for at least 48 hours after adjustment for confounding factors, the authors concluded that RBC transfusion was independently associated with VAP $(p<0.05)$ and that patients who received more than $2 \mathrm{U}$ of PRBCs had a more than twofold increased risk of developing VAP.

Table 1: Studies on the main effects of transfusion-related immunomodulation.

\begin{tabular}{|c|c|c|c|c|c|}
\hline Authors & $\begin{array}{c}\text { Year of } \\
\text { publication }\end{array}$ & Type of Study & $\begin{array}{l}\text { Transfusion-related } \\
\text { infection }\end{array}$ & $\begin{array}{l}\text { Increase in } \\
\text { transfusion- } \\
\text { related mortality }\end{array}$ & $\begin{array}{c}\text { Blood } \\
\text { component }\end{array}$ \\
\hline Rogers et al. ${ }^{47}$ & 2006 & Cohort & $\begin{array}{l}\text { Infection of respiratory, } \\
\text { digestive and urinary } \\
\text { tracts, cardiac infection, } \\
\text { and sepsis }\end{array}$ & Yes & PRBC \\
\hline Banbury et al. ${ }^{46}$ & 2006 & Retrospective & $\begin{array}{l}\text { Bacteremia, sepsis, } \\
\text { sternal infection, and } \\
\text { deep infection in surgical } \\
\text { site }\end{array}$ & Not available & $\begin{array}{c}\text { PRBC, FFP, PC } \\
\text { and CR }\end{array}$ \\
\hline Walz et al. ${ }^{48}$ & 2006 & $\begin{array}{l}\text { Retrospective } \\
\text { Multicenter }\end{array}$ & $\begin{array}{l}\text { Deep infection in surgical } \\
\text { site }\end{array}$ & Not available & PRBC \\
\hline Chaiwat et al. ${ }^{49}$ & 2009 & $\begin{array}{l}\text { Retrospective } \\
\text { Multicenter }\end{array}$ & ARSD & Yes & PRBC \\
\hline Bernard et al. ${ }^{50}$ & 2009 & $\begin{array}{l}\text { Prospective } \\
\text { Multicenter }\end{array}$ & $\begin{array}{l}\text { Pneumonia, sepsis, and } \\
\text { deep infection in surgical } \\
\text { site }\end{array}$ & Yes & PRBC \\
\hline Shorr et al..$^{51}$ & 2005 & $\begin{array}{l}\text { Prospective } \\
\text { Multicenter }\end{array}$ & $\begin{array}{l}\text { Increased probability of } \\
\text { infection }\end{array}$ & Not available & PRBC \\
\hline Zilberberg et al..$^{52}$ & 2007 & $\begin{array}{c}\text { Cohort } \\
\text { Multicenter }\end{array}$ & ARSD & Not available & PRBC \\
\hline Shorr et al ${ }^{53}$ & 2004 & $\begin{array}{l}\text { Retrospective } \\
\text { Multicenter }\end{array}$ & $\begin{array}{l}\text { Ventilator-associated } \\
\text { pneumonia }\end{array}$ & Not available & PRBC \\
\hline Sarani et al. ${ }^{54}$ & 2008 & Retrospective & $\begin{array}{l}\text { Ventilator-associated } \\
\text { pneumonia, bloodstream } \\
\text { infection, and sepsis }\end{array}$ & Not available & FFP \\
\hline
\end{tabular}

PRBC=packed red blood cells; $\mathrm{PC}=$ platelet concentrate; FFP=frozen fresh plasma; $C R=$ cryoprecipitate; $A R D S=$ acute respiratory distress syndrome. 
Most studies aimed to investigate the relationship between PRBC transfusion and immunomodulation, but Banbury et al. ${ }^{46}$ analyzed the association of transfusion with PRBCs, platelet concentrates, Fresh Frozen Plasma (FFP), and cryoprecipitate with postoperative infection. Results showed that, in general, a greater use of PRBCs was associated with a higher probability of infection. However, patients who received an average of six or more $\mathrm{RBC}$ units together with FFP or platelet concentrates had a lower probability of developing deep sternal wound infection compared to those who received only PRBCs. This finding was attributed to the fact that the patient receives a greater amount of IgG and IgM antibodies from the donor dissolved in FFP and platelet concentrates than in PRBCs, which would help in fighting against recipient infections ${ }^{46}$. Moreover, Sarani et al ${ }^{54}$ found that FFP transfusion was associated with increased risk of several types of infection in critical patients, except for catheterrelated sepsis. However, the fact that their study was retrospective makes it difficult to establish a causal relationship between FFP transfusion and infectious complications. Previous investigations suggest that transfusion of soluble proteins in FFP may cause immunosuppression similar to that possibly observed in PRBC transfusion. These proteins may include HLA molecules or fibrinogen/fibrin, which show immunosuppressive properties and are found in FFP55-57.

\section{Prevention of TRIM}

The use of leukocyte reduction filters to prevent TRIM has been widely studied in the literature ${ }^{58-62}$. More than $99.9 \%$ of leukocytes are removed when RBC units pass through these filters before or after storage $^{8}$. Another technique commonly used in many European countries is the transfusion of buffy-coat depleted $\mathrm{RBCs}^{63,64}$, which are obtained through a process that removes nearly two thirds of white cells without using filters as the result of the separation of whole blood into blood components 8 .

There are also other methods to reduce immunomodulation, such as autologous blood donation ${ }^{65}$ or the transfusion of blood components with shorter storage time ${ }^{64}$, but both have been little studied in recent years. Table 2 presents a description of studies

Table 2: Studies assessing TRIM prophylaxis.

\begin{tabular}{|c|c|c|c|c|}
\hline Authors & $\begin{array}{c}\text { Year of } \\
\text { publication }\end{array}$ & Type of study & $\begin{array}{l}\text { Techniques } \\
\text { used }\end{array}$ & Results/Conclusion \\
\hline Fergusson et al..$^{58}$ & 2004 & Randomized & NLR vs LRPR & Infection and mortality $<$ LPRBC $^{*}$ \\
\hline Phelan et al. ${ }^{59}$ & 2007 & Retrospective & LR vs NLR & $\begin{array}{l}\text { No difference was observed between the two } \\
\text { techniques in terms of mortality, length of } \\
\text { hospital stay, and interventions }\end{array}$ \\
\hline Fung et al. ${ }^{60}$ & 2004 & $\begin{array}{l}\text { Double blind } \\
\text { Randomized }\end{array}$ & CHL vs LRPR & $\begin{array}{l}\text { No difference was observed between the two } \\
\text { techniques in terms of acute lung injury and ARDS. }\end{array}$ \\
\hline Bilgin et al. ${ }^{63}$ & 2004 & $\begin{array}{l}\text { Double blind } \\
\text { Randomized }\end{array}$ & PS-LR vs BCD & $\begin{array}{l}\text { Mortality twice as high with } B C D^{*} \text {. Lower infection } \\
\text { rates with PS-LR* }\end{array}$ \\
\hline $\begin{array}{l}\text { van de } \\
\text { Watering et al. }{ }^{64}\end{array}$ & 2006 & Retrospective & $\mathrm{ST}$ in $\mathrm{BCD}$ & The higher storage time, the lower mortality \\
\hline Innerhofer et al. ${ }^{65}$ & 2005 & $\begin{array}{l}\text { Prospective } \\
\text { Observational }\end{array}$ & $A B D$ vs $L R$ & Infection: LR>ABD* \\
\hline Llewelyn et al. ${ }^{66}$ & 2004 & Retrospective & NLR vs PS-LR & $\begin{array}{l}\text { No difference was observed between the two } \\
\text { techniques in terms of length of hospital stay and } \\
\text { infection }\end{array}$ \\
\hline Fung et al. ${ }^{67}$ & 2004 & Cohort & NLR vs PS-LR & $\begin{array}{l}\text { Length of hospital stay: < PS-LR*; Mortality: } \\
\text { no difference was observed between the two } \\
\text { techniques }\end{array}$ \\
\hline Phelan et al. ${ }^{68}$ & 2007 & Cohort & NLR vs PS-LR & $\begin{array}{l}\text { No difference was observed between the two } \\
\text { techniques in terms of length of hospital stay and } \\
\text { mortality }\end{array}$ \\
\hline Nathens et al. 69 & 2006 & $\begin{array}{l}\text { Double blind } \\
\text { Randomized }\end{array}$ & NLR vs PS-LR & $\begin{array}{l}\text { No difference was observed between the two } \\
\text { techniques in terms of length of hospital stay, } \\
\text { mortality, and infection }\end{array}$ \\
\hline Watkins et al. ${ }^{70}$ & 2008 & $\begin{array}{l}\text { Double blind } \\
\text { Randomized }\end{array}$ & NLR vs PS-LR & $\begin{array}{l}\text { No difference was observed between the two } \\
\text { techniques in terms of acute lung injury and ARDS }\end{array}$ \\
\hline
\end{tabular}


on TRIM prophylaxis ${ }^{58-68}$. One of the procedures mentioned in literature is intraoperative autologous blood transfusion, a method in which blood collected during the surgical procedure by suction from the surgical site or from the extracorporeal circulation circuit is centrifuged, washed and filtered, and then reinfused into the patient during or immediately after surgery ${ }^{71,72}$. According to previous research, in addition to possibly preventing TRIM, intraoperative autologous blood transfusion has advantages such as:

- Removal of leukocytes activated by extracorporeal circulation in cardiac surgery ${ }^{73}$;

- Lower RBC transfusion in cardiac surgeries ${ }^{74-76}$, orthopedic surgeries ${ }^{77-79}$, and in liver transplantation ${ }^{80}$;

- Improvement in hemoglobin concentration after surgery ${ }^{73}$.

- Strategy for blood management safer for the patient ${ }^{81}$.

\section{Final Considerations}

It can be observed that no consensus has been achieved regarding immunomodulatory mechanisms related to the use of blood components or regarding which is the best way to prevent TRIM. This lack of consensus is believed to result from the fact that the immune system is extremely complex and its functioning has not been completely understood yet. Some studies have demonstrated that immunosuppression increases proportionally with the number of transfusions ${ }^{5-7}$, which shows the importance of well established protocols and an active transfusion committee. Based on previous research showing that intraoperative cell saving procedures may reduce the number of transfusions, a literature review aimed to search for studies on the association between this technique and decreased immunomodulation was performed using the following keywords: cell saver, immunosuppression, and immunomodulation. Although not finding any study related to this topic, this review allowed us to investigate the differences in the evolution of patients who received leukocyte-filtered blood, buffy-coat depleted RBCs, or blood components with shorter storage time ${ }^{58-62}$. According to the researchers, these data should be discussed so as to establish the cost-benefit relationship of observing the storage time of the blood component and expanding the use of filtered blood components or buffy-coat depleted RBCs in patients who will knowingly receive regular or multiple transfusions after surgery. Because of their debilitated status, patients who need transfusion are usually immunosuppressed and thus more predisposed to infection, a fact that creates a major bias and raises difficulties for randomized studies. Therefore, further studies are needed to elucidate the mechanisms involved in imunomodulation and the implication of this phenomenon for patients, which would help to determine the best strategy to prevent immunomodulatory events.

\section{REFERENCES}

1. Roback JD, Combs MR, Grossman BJ, Hillyer CD. Technical manual. 16th ed. Bethesda: American Association of Blood Banks; 2008. p. 569-93.

2. Opelz G, Sengar DP, Mickey MR, Terasaki PI. Effect of blood transfusions on subsequent kidney transplants. Transplant Proc. 1973;5(1):253-9. PMid:4572098.

3. Cicciarelli JC, Iwaki Y. Direct transfusion effects in organ transplantation. In: Singal DP, editor. Immunological effects of blood transfusion. Boca Raton: CRC Press; 1994. p. 43-61.

4. Opelz G, Vanrenterghem Y, Kirste G, Gray DW, Horsburgh T, Lachance JG, et al. Prospective evaluation of pretransplant blood transfusions in cadaver kidney recipients. Transplantation. 1997;63(7):964-7. http://dx.doi.org/10.1097/00007890199704150-00010. PMid:9112348
5. Blumberg N, Heal JM. Effects of transfusion on immune function. Cancer recurrence and infection. Arch Pathol Lab Med. 1994;118(4):371-9. PMid:8166587.

6. Jensen LS, Andersen AJ, Christiansen PM, Hokland P, Juhl CO, Madsen $\mathrm{G}$, et al. Postoperative infection and natural killer cell function following blood transfusion in patients undergoing elective colorectal surgery. Br J Surg. 1992;79(6):513-6. http:// dx.doi.org/10.1002/bjs.1800790613. PMid:1611441

7. Vamvakas EC, Blajchman MA. Transfusion-related immunomodulation (TRIM): an update. Blood Rev. 2007;21(6):327-48. http:// dx.doi.org/10.1016/j.blre.2007.07.003. PMid:17804128

8. Vamvakas EC. Pneumonia as a complication of blood product transfusion in the critically ill: transfusion-related immunomodulation (TRIM). Crit Care Med. 2006;34(5 Suppl):S151-9. http://dx.doi.org/10.1097/01. CCM.0000214310.70642.8C. PMid:16617260

9. Kirkley SA. Proposed mechanisms of transfusion-induced immunomodulation. Clin Diagn Lab Immunol. 1999;6(5):652-7. PMid:10473511.

10. Vamvakas EC. Meta-analysis of randomized controlled trials investigating the risk of postoperative infection in association with white blood cell-containing allogeneic blood transfusion: the effects of the type of transfused red blood cell product and surgical setting. Transfus Med Rev. 2002;16(4):304-14. http:// dx.doi.org/10.1053/tmrv.2002.35209. PMid:12415516

11. Gorczynski RM, Hadidi S, Yu G, Clark DA. The same immunoregulatory molecules contribute to successful 
pregnancy and transplantation. $A m$ $J$ Reprod Immunol. 2002;48(1):1826. http://dx.doi.org/10.1034/j.16000897.2002.01094.x. PMid:12322892

12. Clark DA, Gorczynski RM, Blajchman MA. Transfusionrelated immunomodulation due to peripheral blood dendritic cells expressing the CD200 tolerance signaling molecule and alloantigen. Transfusion. 2008;48(5):814-21. http://dx.doi.org/10.1111/j.15372995.2008.01654.x. PMid:18298594

13. Barclay AN, Wright GJ, Brooke G, Brown MH. CD200 and membrane protein interactions in the control of myeloid cells. Trends Immunol. 2002;23(6):285-90. http://dx.doi. org/10.1016/S1471-4906(02)02223-8. PMid:12072366

14. Hellings $S$, Blajchman MA. Transfusion-related immunosupression. Transplantation. 2009;10:231-4.

15. Beko KR 2ND, Tran HO, Hewitt CW, Black KS, Patel MP, Ramsamooj $\mathrm{R}$, et al. Mechanisms of prior blood transfusion-cyclosporine-induced tolerance: a potential role for immunecellular chimerism. Transplant Proc. 1991;23(1 Pt 1):147-8. PMid:1990500.

16. Dzik WH. Mononuclear cell microchimerism and the immunomodulatory effect of transfusion. Transfusion. 1994;34(11):1007-12. http:// dx.doi.org/10.1046/j.15372995.1994.341195065024.x. PMid:7974696

17. Blajchman MA, Dzik S, Vamvakas EC, Sweeney J, Snyder EL. Clinical and molecular basis of transfusioninduced immunomodulation: summary of the proceedings of a state-of-theart conference. Transfus Med Rev. 2001;15(2):108-35. http://dx.doi. org/10.1053/tmrv.2001.22614. PMid:11309732

18. Vamvakas EC. Possible mechanisms of allogeneic blood transfusionassociated postoperative infection. Transfus Med Rev. 2002;16(2):14460. http://dx.doi.org/10.1053/ tmrv.2002.31463. PMid:11941576

19. Reed W, Lee TH, Norris PJ, Utter $\mathrm{GH}$, Busch MP. Transfusionassociated microchimerism: a new complication of blood transfusions in severely injured patients. Semin Hematol. 2007;44(1):2431. http://dx.doi.org/10.1053/j. seminhematol.2006.09.012. PMid:17198844

20. Nielsen HJ. Detrimental effects of perioperative blood transfusion. $\mathrm{Br}$ J Surg. 1995;82(5):582-7. http:// dx.doi.org/10.1002/bjs.1800820505. PMid:7613921

21. Mynster T, Nielsen HJ, and the T. Mynster, H. J. Nielsen. The impact of storage time of transfused blood on postoperative infectious complications in rectal cancer surgery. Danish RANX05 Colorectal Cancer Study Group. Scand J Gastroenterol. 2000;35(2):212-7. http://dx.doi. org/10.1080/003655200750024416. PMid:10720122

22. Vamvakas EC, Blajchman MA. Prestorage versus poststorage white cell reduction for the prevention of the deleterious immunomodulatory effects of allogeneic blood transfusion. Transfus Med Rev. 2000;14(1):23-33. http://dx.doi.org/10.1016/S08877963(00)80113-3. PMid:10669938

23. Humbert JR, Fermin CD, Winsor EL. Early damage to granulocytes during storage. Semin Hematol. 1991;28(3 Suppl 5):10-3. PMid:1925636.

24. Vamvakas EC, Carven JH. Allogeneic blood transfusion and postoperative duration of mechanical ventilation. Transfusion. 2001;41(7):88592. http://dx.doi.org/10.1046/ j.1537-2995.2001.41070885.x. PMid:11452156

25. Bury TB, Corhay JL, Radermecker MF. Histamine-induced inhibition of neutrophil chemotaxis and T-lymphocyte proliferation in man. Allergy. 1992;47(6):624-9. http:// dx.doi.org/10.1111/j.1398-9995.1992. tb02385.x. PMid:1285569

26. Silliman CC, Voelkel NF, Allard JD, Elzi DJ, Tuder RM, Johnson JL, et al. Plasma and lipids from stored packed red blood cells cause acute lung injury in an animal model. J Clin Invest. 1998;101(7):1458-67. http://dx.doi. org/10.1172/JCI1841. PMid:9525989

27. Nielsen HJ, Reimert CM, Pedersen AN, Brünner N, Edvardsen L, Dybkjaer E, et al. Time-dependent, spontaneous release of white cell- and platelet-derived bioactive substances from stored human blood. Transfusion. 1996;36(11-12):960-5. http://dx.doi.org/10.1046/j.15372995.1996.36111297091738.x. PMid:8937404
28. Ghio M, Contini P, Mazzei C, Brenci S, Barberis G, Filaci G, et al. Soluble HLA class I, HLA class II, and Fas ligand in blood components: a possible key to explain the immunomodulatory effects of allogeneic blood transfusions. Blood. 1999;93(5):1770-7. PMid:10029607.

29. Puppo F, Contini P, Ghio M, Brenci S, Scudeletti M, Filaci G, et al. Soluble human MHC class I molecules induce soluble Fas ligand secretion and trigger apoptosis in activated CD8(+) Fas (CD95)(+) T lymphocytes. Int Immunol. 2000;12(2):195-203. http:// dx.doi.org/10.1093/intimm/12.2.195. PMid:10653855

30. Pitti RM, Marsters SA, Lawrence DA, Roy M, Kischkel FC, Dowd $P$, et al. Genomic amplification of a decoy receptor for Fas ligand in lung and colon cancer. Nature. 1998;396(6712):699-703. http://dx.doi. org/10.1038/25387. PMid:9872321

31. Ashkenazi A, Dixit VM. Death receptors: signaling and modulation. Science. 1998;281(5381):13058. http://dx.doi.org/10.1126/ science.281.5381.1305 PMid:9721089

32. Dzik WH. Apoptosis, TGF beta and transfusion-related immunosuppression: Biologic versus clinical effects. Transfus Apheresis Sci. 2003;29(2):127-9. http://dx.doi. org/10.1016/S1473-0502(03)00115-0. PMid:12941349

33. Tartter PI, Mohandas K, Azar P, Endres J, Kaplan J, Spivack M. Randomized trial comparing packed red cell blood transfusion with and without leukocyte depletion for gastrointestinal surgery. Am J Surg. 1998;176(5):462-6. http://dx.doi. org/10.1016/S0002-9610(98)00245-1. PMid:9874434

34. Buelow R, Burlingham WJ, Clayberger C. Immunomodulation by soluble HLA class I. Transplantation. 1995;59(5):649-54. http://dx.doi. org/10.1097/00007890-19950315000001. PMid:7886787

35. Shirwan H, Mhoyan A, Leamer M, Wang C, Cramer DV. The role of donor class I major histocompatibility complex peptides in the induction of allograft tolerance. Transplant Proc. 1997;29(1-2):1134-5. http://dx.doi. org/10.1016/S0041-1345(96)00468-X. PMid:9123235

36. Magee CC, Sayegh MH. Peptide 
mediated immunosuppression: new developments. Transplant Proc. 1998;30(5):2131-5. http://dx.doi. org/10.1016/S0041-1345(98)00563-6. PMid:9723416

37. Chueh SC, Tian L, Wang M, Wang ME, Stepkowski SM, Kahan BD. Induction of tolerance toward rat cardiac allografts by treatment with allochimeric class I MHC antigen and FTY720. Transplantation. 1997;64(10):1407-14. http://dx.doi. org/10.1097/00007890-19971127000006. PMid:9392303

38. Naji A. Induction of tolerance by intrathymic inoculation of alloantigen. Curr Opin Immunol. 1996;8(5):704-9. http://dx.doi.org/10.1016/S09527915(96)80089-6. PMid:8902397

39. Chowdhury NC, Murphy B, Sayegh $\mathrm{MH}$, Jin MX, Roy DK, Hardy MA, et al. Acquired systemic tolerance to rat cardiac allografts induced by intrathymic inoculation of synthetic polymorphic MHC class I allopeptides. Transplantation. 1996;62(12):1878-82. http://dx.doi.org/10.1097/00007890199612270-00034. PMid:8990380

40. Braud VM, McMichael AJ. Regulation of NK cell functions through interaction of the CD94/NKG2 receptors with the nonclassical class I molecule HLA-E. Curr Top Microbiol Immunol. 1999;244:85-95. http://dx.doi. org/10.1007/978-3-642-58537-1 7. PMid:10453651

41. Baumgartner JM, Silliman CC, Moore EE, Banerjee A, McCarter MD. Stored red blood cell transfusion induces regulatory $T$ cells. $J$ Am Coll Surg. 2009;208(1):1109. http://dx.doi.org/10.1016/j. jamcollsurg.2008.08.012. PMid:19228512

42. Abbas AK, Lichtman AH. Imunologia básica: funções e distúrbios do sistema imunológico. 2nd ed. Rio de Janeiro: Elsevier; 2007. p. 186-8.

43. Brunson ME, Alexander JW. Mechanisms of transfusioninduced immunosuppression. Transfusion. 1990;30(7):651-8. http://dx.doi.org/10.1046/j.15372995.1990.30790385527.x. PMid:2205953

44. Blajchman MA, Bordin JO. Mechanisms of transfusionassociated immunosuppression. Curr Opin Hematol. 1994;1(6):457-61. PMid:9371323.
45. Reed E, Hardy M, Benvenisty A, Lattes C, Brensilver J, McCabe $\mathrm{R}$, et al. Effect of antiidiotypic antibodies to HLA on graft survival in renal-allograft recipients. $N$ Engl J Med. 1987;316(23):14505. http://dx.doi.org/10.1056/ NEJM198706043162305. PMid:3553951

46. Banbury MK, Brizzio ME, Rajeswaran J, Lytle BW, Blackstone $\mathrm{EH}$. Transfusion increases the risk of postoperative infection after cardiovascular surgery. $J$ Am Coll Surg. 2006;202(1):1318. http://dx.doi.org/10.1016/j. jamcollsurg.2005.08.028. PMid:16377506

47. Rogers MA, Blumberg N, Saint SK, Kim C, Nallamothu BK, Langa KM. Allogeneic blood transfusions explain increased mortality in women after coronary artery bypass graft surgery. Am Heart J. 2006;152(6):102834. http://dx.doi.org/10.1016/j. ahj.2006.07.009. PMid:17161047

48. Walz JM, Paterson CA, Seligowski JM, Heard SO. Surgical site infection following bowel surgery: a retrospective analysis of 1446 patients. Arch Surg. 2006;141(10):1014-8, discussion 1018. http://dx.doi. org/10.1001/archsurg.141.10.1014. PMid:17043280

49. Chaiwat O, Lang JD, Vavilala MS, Wang J, MacKenzie EJ, Jurkovich GJ, et al. Early packed red blood cell transfusion and acute respiratory distress syndrome after trauma. Anesthesiology. 2009;110(2):35160. http://dx.doi.org/10.1097/ ALN.0b013e3181948a97. PMid:19164959

50. Bernard AC, Davenport DL, Chang PK, Vaughan TB, Zwischenberger JB. Intraoperative transfusion of $1 \mathrm{U}$ to 2 $\mathrm{U}$ packed red blood cells is associated with increased 30-day mortality, surgical-site infection, pneumonia, and sepsis in general surgery patients. J Am Coll Surg. 2009;208(5):9317, 937.e1-2, discussion 9389. http://dx.doi.org/10.1016/j. jamcollsurg.2008.11.019. PMid:19476865

51. Shorr AF, Jackson WL, Kelly KM, Fu $\mathrm{M}$, Kollef MH. Transfusion practice and blood stream infections in critically ill patients. Chest. 2005;127(5):17228. http://dx.doi.org/10.1378/ chest.127.5.1722. PMid:15888852
52. Zilberberg MD, Carter C, Lefebvre P, Raut M, Vekeman F, Duh MS, et al. Red blood cell transfusions and the risk of acute respiratory distress syndrome among the critically ill: a cohort study. Crit Care. 2007;11(3):R63. http://dx.doi. org/10.1186/cc5934. PMid:17553147

53. Shorr AF, Duh MS, Kelly KM, Kollef $\mathrm{MH}$, and the CRIT Study Group. Red blood cell transfusion and ventilatorassociated pneumonia: A potential link? Crit Care Med. 2004;32(3):66674. http://dx.doi.org/10.1097/01. CCM.0000114810.30477.C3. PMid:15090945

54. Sarani B, Dunkman WJ, Dean L, Sonnad S, Rohrbach JI, Gracias $\mathrm{VH}$. Transfusion of fresh frozen plasma in critically ill surgical patients is associated with an increased risk of infection. Crit Care Med. 2008;36(4):1114-8. http://dx.doi. org/10.1097/CCM.0b013e318168f89d. PMid:18379235

55. Donnell CA, Daniel SJ, Ferrara JJ. Fibrinogen degradation products in fresh frozen plasma. Possible contribution to immunosuppression. Am Surg. 1989;55(8):505-7. PMid:2764399.

56. Rubin H. Systemic effects of cancer: role of multiple proteases and their toxic peptide products. Med Sci Monit. 2005;11(7):RA221-8. PMid:15990698.

57. Hillyer CD, Lankford KV, Roback JD, Gillespie TW, Silberstein LE. Transfusion of the HIV-seropositive patient: immunomodulation, viral reactivation, and limiting exposure to EBV (HHV-4), CMV (HHV-5), and HHV-6, 7, and 8. Transfus Med Rev. 1999;13(1):1-17. http://dx.doi. org/10.1016/S0887-7963(99)80084-4. PMid:9924760

58. Fergusson D, Khanna MP, Tinmouth A, Hébert PC. Transfusion of leukoreduced red blood cells may decrease postoperative infections: two meta-analyses of randomized controlled trials. Can J Anaesth. 2004;51(5):417-24. http:// dx.doi.org/10.1007/BF03018302. PMid:15128625

59. Phelan HA, Sperry JL, Friese RS. Leukoreduction before red blood cell transfusion has no impact on mortality in trauma patients. J Surg Res. 2007;138(1):32-6. http://dx.doi. org/10.1016/j.jss.2006.07.048. PMid:17161430 
60. Fung MK, Rao N, Rice J, Ridenour M, Mook W, Triulzi DJ. Leukoreduction in the setting of open heart surgery: a prospective cohort-controlled study. Transfusion. 2004;44(1):30-5. http://dx.doi.org/10.1111/j.00411132.2003.00601.x. PMid:14692964

61. Refaai MA, Blumberg N. Transfusion immunomodulation from a clinical perspective: an update. Expert Rev Hematol. 2013;6(6):653-63. http:// dx.doi.org/10.1586/17474086.2013.85 0026. PMid:24168641

62. Lannan KL, Sahler J, Spinelli SL, Phipps RP, Blumberg N. Transfusion immunomodulation-the case for leukoreduced and (perhaps) washed transfusions. Blood Cells Mol Dis. 2013;50(1):61-8. http://dx.doi. org/10.1016/j.bcmd.2012.08.009. PMid:22981700

63. Bilgin YM, van de Watering LM, Eijsman L, Versteegh MI, Brand $\mathrm{R}$, van Oers $\mathrm{MH}$, et al. Doubleblind, randomized controlled trial on the effect of leukocytedepleted erythrocyte transfusions in cardiac valve surgery. Circulation. 2004;109(22):275560. http://dx.doi.org/10.1161/01. CIR.0000130162.11925.21. PMid:15148271

64. van de Watering $\mathrm{L}$, Lorinser $\mathrm{J}$, Versteegh M, Westendord R, Brand A. Effects of storage time of red blood cell transfusions on the prognosis of coronary artery bypass graft patients. Transfusion. 2006;46(10):1712-8. http://dx.doi.org/10.1111/j.15372995.2006.00958.x. PMid:17002627

65. Innerhofer P, Klingler A, Klimmer C, Fries D, Nussbaumer W. Risk for postoperative infection after transfusion of white blood cell-filtered allogeneic or autologous blood components in orthopedic patients undergoing primary arthroplasty. Transfusion. 2005;45(1):103-10. http://dx.doi.org/10.1111/j.15372995.2005.04149.x. PMid:15647025

66. Llewelyn CA, Taylor RS, Todd AA, Stevens W, Murphy MF, Williamson LM, and the Leucodepletion Study Group. The effect of universal leukoreduction on postoperative infections and length of hospital stay in elective orthopedic and cardiac surgery. Transfusion. 2004;44(4):489500. http://dx.doi.org/10.1111/j.15372995.2004.03325.x. PMid:15043563
67. Fung MK, Rao N, Rice J, Ridenour M, Mook W, Triulzi DJ. Leukoreduction in the setting of open heart surgery: a prospective cohort-controlled study. Transfusion. 2004;44(1):30-5. http://dx.doi.org/10.1111/j.00411132.2003.00601.x. PMid:14692964

68. Phelan HA, Sperry JL, Friese RS. Leukoreduction before red blood cell transfusion has no impact on mortality in trauma patients. J Surg Res. 2007;138(1):32-6. http://dx.doi. org/10.1016/j.jss.2006.07.048. PMid:17161430

69. Nathens AB, Nester TA, Rubenfeld GD, Nirula R, Gernsheimer TB. The effects of leukoreduced blood transfusion on infection risk following injury: a randomized controlled trial. Shock. 2006;26(4):3427. http://dx.doi.org/10.1097/01. shk.0000228171.32587.a1. PMid:16980879

70. Watkins TR, Rubenfeld GD, Martin TR, Nester TA, Caldwell E, Billgren $\mathrm{J}$, et al. Effects of leukoreduced blood on acute lung injury after trauma: a randomized controlled trial. Crit Care Med. 2008;36(5):14939. http://dx.doi.org/10.1097/ CCM.0b013e318170a9ce. PMid:18434890

71. Naumenko KS, Kim SF, Cherkanova MS, Naumenko SE. The Haemonetics Cell Saver 5 washing properties: effect of different washing pump and centrifuge speeds. Interact Cardiovasc Thorac Surg. 2008;7(5):759-63. http:// dx.doi.org/10.1510/icvts.2008.183582. PMid:18635585

72. Santrach PJ. Standard for perioperative autologous blood collection and administration. 1st ed. Bethesda: American Association of Blood Banks; 2001.

73. Jewell AE, Akowuah EF, Suvarna SK, Braidley P, Hopkinson D, Cooper G. A prospective randomised comparison of cardiotomy suction and cell saver for recycling shed blood during cardiac surgery. Eur J Cardiothorac Surg. 2003;23(4):633-6. http://dx.doi. org/10.1016/S1010-7940(02)00834-5. PMid:12694789

74. Grogan K, Stearns J, Hogue CW. Brain protection in cardiac surgery. Anesthesiol Clin. 2008;26(3):52138. http://dx.doi.org/10.1016/j. anclin.2008.03.003. PMid:18765221
75. Englberger L, Streich M, Tevaearai $\mathrm{H}$, Carrel TP. Different anticoagulation strategies in off-pump coronary artery bypass operations: a European survey. Interact Cardiovasc Thorac Surg. 2008;7(3):378-82. http://dx.doi. org/10.1510/icvts.2007.169086. PMid: 18303040

76. Niranjan G, Asimakopoulos G, Karagounis A, Cockerill G, Thompson $M$, Chandrasekaran V. Effects of cell saver autologous blood transfusion on blood loss and homologous blood transfusion requirements in patients undergoing cardiac surgery onversus off-cardiopulmonary bypass: a randomised trial. Eur J Cardiothorac Surg. 2006;30(2):271-7. http://dx.doi. org/10.1016/j.ejcts.2006.04.042. PMid:16829083

77. Huët C, Salmi LR, Fergusson D, Koopman-van Gemert AW, Rubens F, Laupacis A, and the International Study of Perioperative Transfusion (ISPOT) Investigators. A metaanalysis of the effectiveness of cell salvage to minimize perioperative allogeneic blood transfusion in cardiac and orthopedic surgery. Anesth Analg. 1999;89(4):861-9. http://dx.doi org/10.1213/00000539-19991000000009. PMid:10512256

78. Reitman CA, Watters WC 3RD, Sassard WR. The Cell Saver in adult lumbar fusion surgery: a cost-benefit outcomes study. Spine. 2004;29(14):1580-3, discussion 1584. http://dx.doi.org/10.1097/01. BRS.0000131433.05946.4F. PMid:15247582

79. Nicolai P, Leggetter PP, Glithero PR, Bhimarasetty CR. Autologous transfusion in acetabuloplasty in children. J Bone Joint Surg Br. 2004;86(1):110-2. PMid:14765876.

80. Sankarankutty AK, Teixeira AC, Souza FF, Mente ED, Oliveira GR, Almeida RC, et al. Impact of blood salvage during liver transplantation on reduction in transfusion requirements. Acta Cir Bras. 2006;21(Suppl 1):44-7. http://dx.doi.org/10.1590/S010286502006000700011 . PMid:17013513

81. Nieder AM, Manoharan M, Yang Y, Soloway MS. Intraoperative cell salvage during radical cystectomy does not affect long-term survival. Urology. 2007;69(5):8814. http://dx.doi.org/10.1016/j. urology.2007.01.060. PMid:17482926 